\title{
The Origin, Prevalence, Diagnosis and Treatment of COVID- 19: An Overview
}

\author{
Mahideen Afridi ${ }^{*}$, Khurshid Ahmad ${ }^{2 \#}$, Nasir Ali Khan ${ }^{3}$, Abid Khan $^{4}$, Feifei Wang ${ }^{2}$, Faiza Yaseen ${ }^{5}$ \\ ${ }^{1}$ National Center for Bioinformatics, Quaid-i-Azam University \\ Islamabad, Pakistan \\ ${ }^{2}$ Collage of Food Science and Engineering, Ocean University of China \\ Qingdao, Shandong Province, P. R. China \\ ${ }^{3}$ Department of Microbiology, Quaid-i-Azam University \\ Islamabad, Pakistan \\ ${ }^{4}$ Center of Biotechnology \& Microbiology (COBAM), University of Peshawar \\ Peshawar, Pakistan \\ ${ }^{5}$ Collage of Marine Life Sciences, Ocean University of China \\ Qingdao, Shandong Province, P. R. China \\ *Corresponding author's email: Mahidkhanafridi [AT] gmail.com \\ \#Corresponding author's email: khurshid.msbt361[AT\}iiu.edu.pk
}

\begin{abstract}
The outbreak of COVID-19 was emerged initially in Hubei province of China in December 2019 then quickly spread throughout the world. The World Health Organization (WHO) confirmed it a public health emergency of global concern and is causing cumulative alarm. The International Committee on Taxonomy of Viruses (ICTV) named acute respiratory syndrome coronavirus 2 (SARS-CoV-2). COVID-19 virus is composed of ssRNA having 60$120 \mathrm{~nm}$ of genomic diameter. It has high infection ability and a low mortality rate then (SARS-CoV and MERS-CoV). Now a vaccine has been developed for the treatment of COVID-19. The prevention of existing viruses must be followed by WHO guidance i.e. social separation, washing hands regularly, disinfecting use in the workplace and home. Here we summarize the origin, prevalence, diagnosis, treatments, as well listed of vaccines against the COVID-19 virus. The main aim of the current review article comprises data obtained from current research papers and WHO recommendations to prevention, care, trial with a new investigation of research, treatment, an invention of updated vaccines, and provide bibliophiles through the present information on the emerging contagious outbreak.
\end{abstract}

Keywords-COVID-19, Vaccines, WHO, SARS-CoV-2, Viruses, Pandemic and vaccine

\section{INTRODUCTION}

In the last of 2019, unknown pneumonia was reported in the Hubei province, Wuhan, China. The clinical features of unidentified disease were the same as those of virus-related pneumonia patient. Later the analysis was completed with the respirational sample, expert setting by the side of PCR Centre intended on diseases minimize. Such variation of pneumonia was affected by a novel virus later, identified as innovative coronavirus pneumonia [1]. The WHO formally assumed it a name COVID-19 viral disease. Similarly, it is also called severe acute respiratory syndrome coronavirus 2 (SARS-CoV-2) by the International Committee on Taxonomy of Viruses. The COVID-19 virus belongs to a vast class of virus's family $\beta$ coronavirus, which is widespread in nature. COVID-19 virus has numerous probable intermediate hosts, final hosts, and natural hosts as compared to other viruses. In such a way, produces a massive challenge for the prevention, care and treatment of viral disease. The novel coronavirus has a high rate of transmission, infection ability, and low mortality rate as compared to SARS-CoV-2 and MERS-CoV [2].

So far, coronavirus has rapidly spread in above 223 nation-states throughout the world causing 164523894 confirmed cases and deaths occurs approximately 3412032 as of 20 May 2021. Considering the worldwide threat, the WHO acknowledged coronavirus infection as a public health emergency of global concerns (PHEGC). Hence, it is important to follow on social guidance, societal separation from crowds, disinfecting use in the workplace, home and washing hands regularly after touching any things [3]. Working with corona infected patients, researcher and investigators must use N95 or FFP3 masks, gloves, lab coats, eyeglasses, and other safety equipment [4]. Avoiding coronavirus disease spreading throughout the country and worldwide level, through stops travelling, train stations, curfews, events postponement, workplace hazard control, screening at airports, and quarantines positive cases carriers[5-7] outgoing passenger travel bans 
$[8,9]$. Furthermore, studying and perceptive of $\mathrm{CoV}-2$ coronavirus is required by discovering vital affecting medicines and vaccines. In a current review, the article summarizes the origin, history, prevalence, structure, diagnosis and treatments of coronavirus patients to sustenance observe up investigation, guidance for vital avoidance, care, treatment, as well as to carry bibliophiles and listed updates discovery of corona vaccines with different countries.

\section{PATHOGENIC AND GENOMIC ORGANIZATION PROCESS OF COVID-19 VIRUS}

Coronaviruses are composed of ssRNA virus having 80-120 nm of genomic diameters. The coronavirus contains four basic types as $\alpha, \beta, \Upsilon$, and $\delta$-coronaviruses [10]. Before this coronavirus, six other viruses were identified to affect illness in a human, together with MERS-CoV as well as SARS-CoV have $\beta$ type coronavirus [11]. When studied about the genomic sequencing which confirm as $79 \%$ similar of SARS-CoV and CoV-2, however, the SARS and SARS-CoV-2 coronaviruses genetic makeup are closer than bat species (MG772933) [12] these coronae originated from a bat SARS coronaviruses. The interesting fact is that several studies have revealed angiotensin-converting enzyme 2 (ACE2) as a receptor of SARSCoV-2 in common with SARS-CoV. The $1 / 3^{\text {rd }}$ region of coronavirus genome form in the structural protein $(\mathrm{S}, \mathrm{E}, \mathrm{M}, \& \mathrm{~N})$ while $2 / 3^{\text {rd }}$ of the replica's gene encoding ORFs, end of sequence presents in poly A-tail which shown in Fig 1.[13].

(A) SARS-CoV

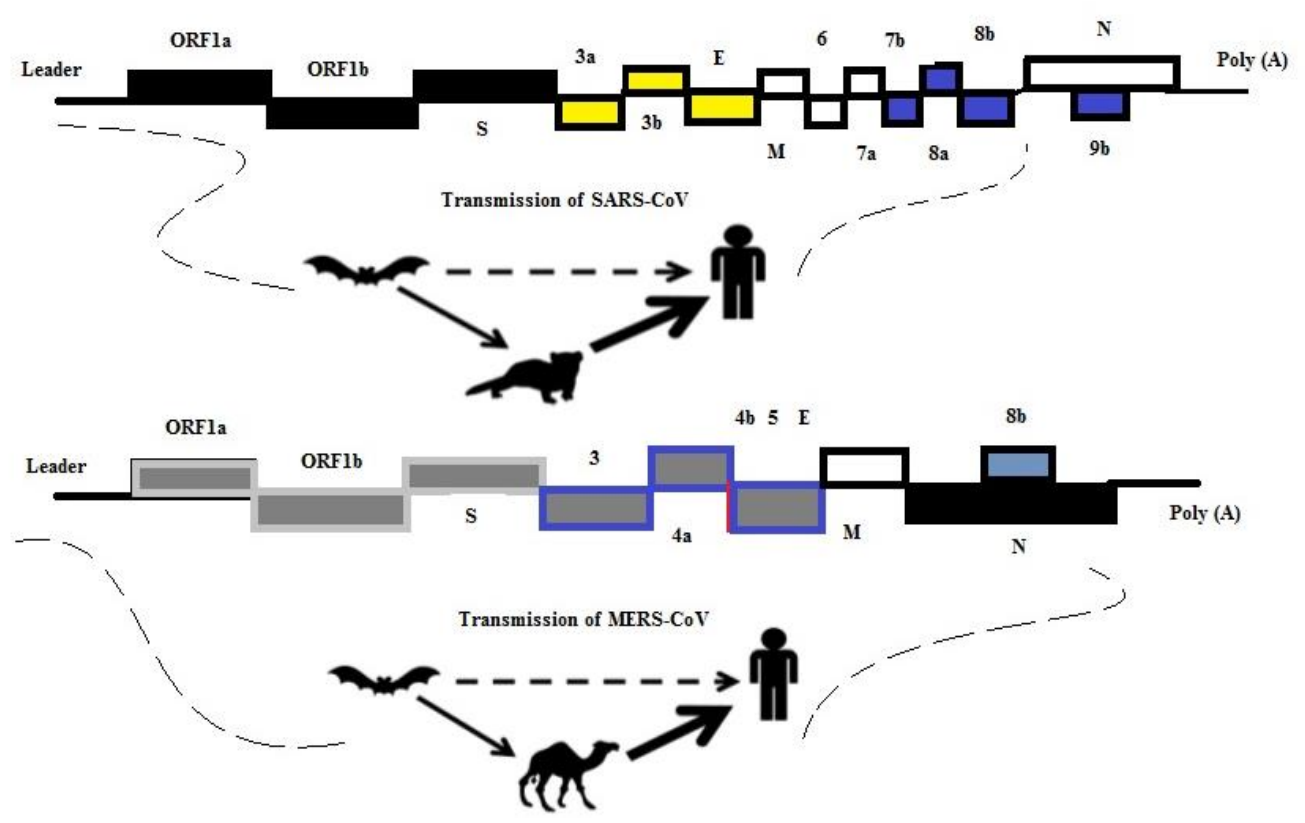

Figure 1: Genomics structures and transmission of SARS-CoV/MERS-CoV viruses

Coronaviruses mainly identify their matching receptor on the specific binding cell surface via the entrance protein of the cell as spike protein which is a significant consequence of contagion. In the examine the structure model of SARS$\mathrm{CoV}-2$ virus bind with receptors to $\mathrm{ACE}_{2}$ with higher than 10 folds, in such a way that SARS-CoV-2 more affinity studied in above discussion than SARS-CoV virus, the investigation of a threshold essential for viral diseases [14]. Therefore, the complete procedure of corona $\mathrm{CoV}-2$ viral infection in a human through binding of spike protein to a basic receptor ACE2, the intensity of the interface for menace transmission via in human of human, in what way corona CoV-2 infected organs, and injury to persists unidentified, as well as further knowledge exists required.

\section{ORIGIN OF CORONA VIRUS}

Zhou and co-worker isolated samples from seven patients and bats, these samples were further carried to the sequencing side and found that this novel coronavirus shared $96.2 \%$ identical with genomic sequence of bat coronavirus RaTG13 from horse-shoe bats Rhinolophus. This finding provided further indication that 2019-nCoV most closely originated from bat [15]. Earlier, investigates that bat was natural hosts of coronaviruses which having the origin and ancestors of SARC-CoV [16]. Therefore, around a few residues of amino acid presents in a variation as CoV-19 coronavirus binding domain when associated is SARS-CoV, that one looks the structure of the receptor-binding domain quiet permitted usage of angiotensin converting enzyme 2 as an entrance receptor. It was proposed that human has no bats hosts via contact [15]. The animal $\mathrm{CoV}$ virus has been identified in the subsequently late 1930s. Previously the first samples obtain of HCoV-229E strain 
B814 from the nasal discharge of the patient, these samples were compared with different CoVs common cold patient had been isolated from different infected animals, such as dog, cat, pig, and mouse [17, 18].

\section{HCoV-229E, HCoV-OC43, SARS-CoV, HCoV-NL63, HCoV-HKUI, MERS-CoV, \& SARS- CoV-2}

The congenital origin of human coronaviruses HCoVs predictable involves main hosts are bat. Hence, genomic makeup provided for an evolutionary origin of the HCoV-229E virus, a type of hipposiderid bat which is an investigation as enormous samples of African bad and characterization with several bat viruses on the complete genomic approach. Therefore, these evolutionary studies conclude that human and animals' viruses are hereditarily closely related, can also possible for the exchange of genetic materials, and form of a single virus species [19]. Furthermore, HCoVs, which are highly pathogenic, originate from zoonotic HCoV-HKU1, HCoV-229E, HCoV-NL63, and HCoV-OC43, which have been studied. The phylogenetic analysis showed that both HCoV-OC43 and HCoV-229E potency have initiated from bat CoV $[20,21]$. The corona like HCoV-OC43 plus HCoV-HKU1 parental viruses also found in rodents these were described that a bat CoV term ARCoV-2 [19].

Moreover, humans find out seven types of coronaviruses, HCoV-OC43 andHCoV-229E were discovered by the 1960s, the other five types were conformed analysis as after 2002. In 2003, the SARS virus infected more than eight thousands people, such virus mortality rate is nearly $10 \%$ and the human corona has received extraordinary courtesy. The other strains of coronavirus such as HCoV-HKU1 as well as HCoV-NL63 were found out in 2004/2005, respectively [22]. From recent investigation and analysis of coronavirus, the scientist reached that point's rodents (rats), as well as bats are the natural reservoir source of the COVID-19 virus. Bats are natural sources of corona such as HCoV-NL63, HCoV-OC43, MERS$\mathrm{CoV}$, and SARS-CoV while HCoV-HKU1 and HCoV-OC43 viruses' natural host are mice. It is currently believed that dromedary is the intermediary host of MERS-CoV plus HCoV-229E viruses, cattle is the intermediary host of HCoVOC43, while civet cat is the intermediary host SARS-CoV type of coronavirus. However, there is not confirmed of SARSCoV-2 virus intermediary host, but some investigators believe that pangolin was the intermediate host of CoV-2 coronavirus [23]. Coronavirus origin, transmission between intra and inter-species to human as shown in Fig 2.

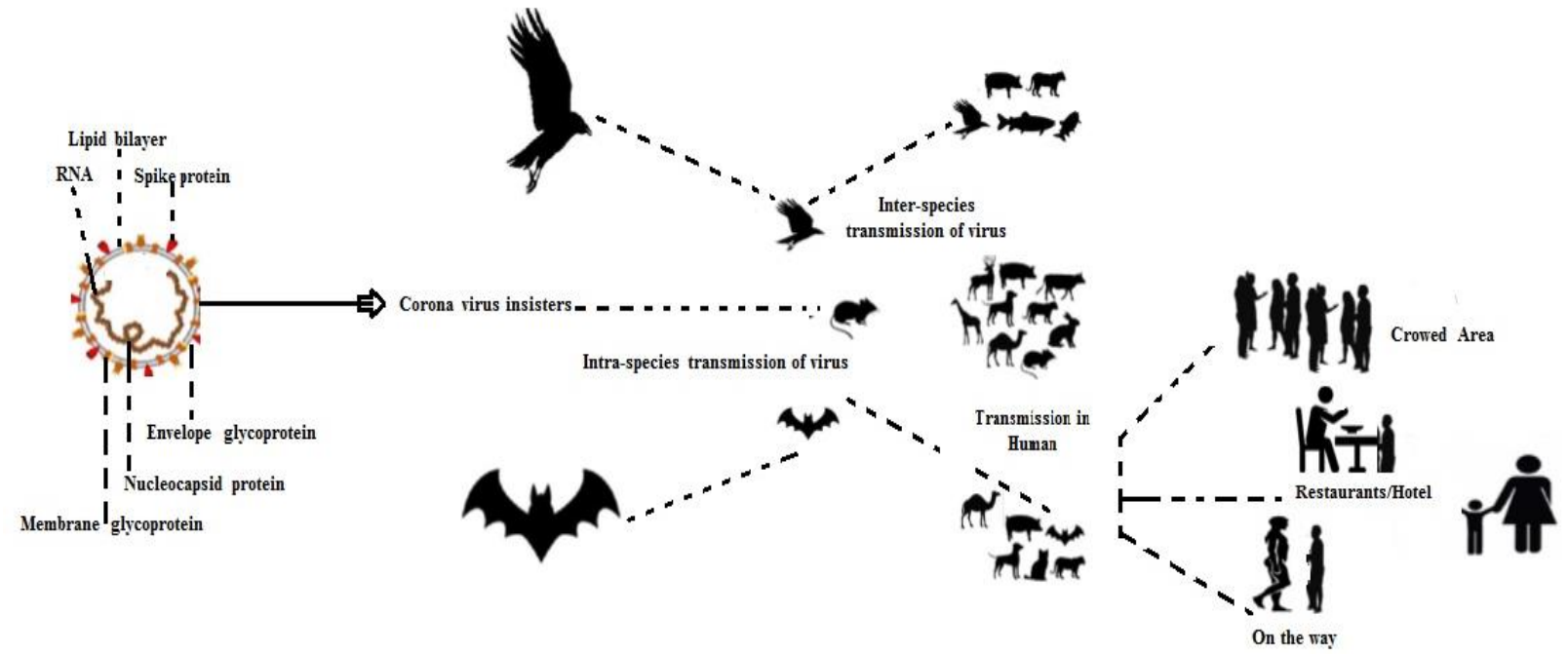

Figure 2: COVID-19 origin, intra-species and interspecies transmissions as well as in human

\section{PREVALENCE OF CORONA VIRUS}

Prevalence is a statistical conception discussing the number of cases of a disease that are existent in a population at a given time, however, prevalence refers to the numerous new cases that arise in a specific period. The principal reproduction number $\left(R_{0}\right)$ illustrate which mean numeral of preliminary ailments that affected persons may begin in a fully susceptive populace short of interference [24]. Approximation of a $R_{o}$ veers within study collaborators is improved as further findings become present. Using the unprotected, Infectious, Removed (SEIR) model for risk reduction, CoV-2 coronavirus was estimated to have a $R_{o}$ of 2.47-2.86 [25]. The researcher used as IDEA-model to find out the $R_{o}$ values is 2.0 to 3.3 [26]. SARS-CoV has a predicted $\mathrm{R}_{\mathrm{o}}$ value of 2.2-3.6, while MERS-CoV has a $\mathrm{R}_{\mathrm{o}}$ value of 2.0-6.7 [27, 28]. The above result of $\beta$-coronavirus SARS-CoV corona has been comparatively high transmission ability than compared to another one. The large research investigation in China finally reached in that points the median age as $47 \%$ of cases as 35-58 years old were inter-quartile, 30-79 years affected cases were $87 \%$, above the 80 age were $3 \%$, as well as female's cases were $41.9 \%$ [29]. Furthermore, corona disease was detected in $75 \%$ of the people of Hubei Province, China. In percentage base of infected cases classification such as $81 \%$ as mild, $14 \%$ severe, and $5 \%$ were classified as critical. The fatality rate (CFR) of overall infected cases were $2.3 \%$, therefore, amongst 70-79 years cases as well as above 80 aged, the CFR range was 
$8 \%$ and $14.8 \%$, correspondingly [30]. The elderly time male was more suspected to CoV-2 coronavirus when co-relate to other collection of sample from those elderly males which have already chronic underlying disease i.e. heart patients, hypertension, and diabetes were more likely affected to coronavirus, for the duration of the severe phase of a pre-pandemic $\mathrm{R}_{\mathrm{o}}$ may be completely unbalanced [31,32].

The study of pregnancy base, the total nine pregnant women who affected with a corona in a late phase of pregnancy proposed outbreak of corona does not indicate into extensively mediocre signs than in nonpregnant woman's, there is no indication for intrauterine disease by vertical transmission [33]. The study of hospital cases, containing 138 coronaviruses proposed that hospital base transmission of SARS-CoV-2 as $41 \%$ happened in patients [34]. Furthermore, an investigation on more than 400 patients found that the number of cases in healthcare employees gradually improved over time [35]. All these affected cases are likely to reflect exposure to a more attentiveness of virus from sustainable interaction with close quarters.

Based on the stander epidemics, the $\mathrm{R}_{\mathrm{o}}$ value is more than 1 which have led to the possible eruption of corona infections. The study of replication level in a CoV-2 coronavirus range use of 2.4-3.3, is varied in relationship with population risk among other parameters, susceptibility, mobility, and containment measures. In this base, each diseased person would consequently infect more than one person's [36]. The evolution period of coronavirus usually ranges from 2 to 14 days, with an average of 5 days, while some instances have incubation times of only one day. Usually, the infection time of coronavirus commencement increase of deadly ailment within in a week [37]. The updated cases list according to WHO till 16 May 2021 as shown in Table 1.

Table 1: Newly reported and cumulative COVID-19 cases and deaths, by WHO Region, as of 16 May 2021

\begin{tabular}{l|l|l|l|l|l|l}
\hline $\begin{array}{l}\text { WHO } \\
\text { Region }\end{array}$ & $\begin{array}{l}\text { New cases in } \\
\text { last 7-days \% }\end{array}$ & $\begin{array}{l}\text { Change } \\
\text { in new } \\
\text { cases in } \\
\text { last 7- } \\
\text { days }\end{array}$ & $\begin{array}{l}\text { Cumulative } \\
\text { cases (\%) }\end{array}$ & $\begin{array}{l}\text { New deaths in last 7 } \\
\text { days (\%) }\end{array}$ & $\begin{array}{l}\text { Change in } \\
\text { new deaths in } \\
\text { last 7 days }\end{array}$ & $\begin{array}{l}\text { Cumulative } \\
\text { deaths (\%) }\end{array}$ \\
\hline Americas & $1201726(25 \%)$ & $-3 \%$ & $\begin{array}{l}64757485 \\
(40 \%)\end{array}$ & $31439(37 \%)$ & $-7 \%$ & $\begin{array}{l}1583343 \\
(47 \%)\end{array}$ \\
\hline Europe & $684903(14 \%)$ & $-26 \%$ & $\begin{array}{l}53565774 \\
(33 \%)\end{array}$ & $16255(19 \%)$ & $-16 \%$ & $\begin{array}{l}1121477 \\
(33 \%)\end{array}$ \\
\hline $\begin{array}{l}\text { Africa } \\
\text { South- } \\
\text { East Asia }\end{array}$ & $2529924(53 \%)$ & $-12 \%$ & $\begin{array}{l}28082564 \\
(17 \%)\end{array}$ & $30881(36 \%)$ & $7 \%$ & $84844(3 \%)$ \\
\hline $\begin{array}{l}\text { Western } \\
\text { Pacific }\end{array}$ & $132757(3 \%)$ & $4 \%$ & $\begin{array}{l}2729890 \\
(2 \%)\end{array}$ & $1304(1 \%)$ & $4 \%$ & 340078 \\
\hline $\begin{array}{l}\text { Eastern } \\
\text { Mediterr } \\
\text { anean }\end{array}$ & $2020035(5 \%)$ & $-22 \%$ & $\begin{array}{l}9648410 \\
(6 \%)\end{array}$ & $4709(5 \%)$ & $-16 \%$ & $40930(1 \%)$ \\
\hline Global & $\begin{array}{l}4809520 \quad(100 \\
(17 \%)\end{array}$ & $-12 \%$ & $\begin{array}{l}162184263 \\
(100 \%)\end{array}$ & $85975(100 \%)$ & $-5 \%$ & $\begin{array}{l}193761 \\
(6 \%)\end{array}$ \\
\hline
\end{tabular}

\section{DIAGNOSIS OF COVID-19}

As of March 27, 2020, China has approved 21 new coronavirus detection kits. As shown in Table 2, the detection methods cover fluorescent PCR method, colloidal gold method, combined probe anchoring polymerization sequencing method, magnetic particle chemiluminescence method and constant temperature amplification-real-time fluorescence method.

The primary consequence of pneumonia was an undiagnosed disease spread throughout the Hubei province, China, identified through clinical features, chest imaging, and the identification of common pathogenic organism such as viral, bacterial, and fungal infections that caused pneumonia [38, 39]. The samples collected from respiratory, nasal swabs, sputum, counting pharyngeal, bronchial aspirates, and bronchoalveolar lavage was tested for communal viruses such as SARS-CoV, MERS-CoV, parainfluenza virus, influenza, syncytial, rhinovirus, and adenovirus, used as quantitative PCR 
(qRT-PCR) for analyses permitted by drug administration and Chinese food, scheduled infection causes microbe bacteria and fungi fungal inspections were completed formerly throughout a $1^{\text {st }}$ week Jan 2020 . The novel coronavirus, which was given a name 2019-nCoV, was isolated from inferior respiratory tract, and a test for it was established after that. The researcher successfully collected updates on 2019-nCoV virus cell culture as well as genetic sequencing in laboratories all over the world to track the advancement of polymerase chain-tests to diagnose viral disease [40, 41 \& 42].

Recently, the most detection techniques used for Lab testing for the coronavirus are antigen/antibodies and nucleic acid. Rapid and precise diagnosis of novel coronavirus is vital to control the epidemic of CoV-2 coronavirus. The primary tool used in the laboratory for corona viral disease detection is the nucleic acid analysis test. Quantitative real-time PCR (qRT-PCR) is a molecular genetic detection technique based on the nucleic acid (NA) sequences. In GenBank the whole genome of COVID-19 is available. As a result, the nucleic acid of COVID-19 was examined by quantitative real-time qRTPCR or sequencing by viral genomic oropharyngeal and nasopharyngeal swabs, blood sample, sputum and stools [43, 44]. However, assembling these sample kinds by healthcare workers needs adjacent interaction with an infected person, posing a risk of spreading the coronavirus transmitting to healthcare personnel. Furthermore, isolation of oropharyngeal and nasopharyngeal samples sometimes happened to bleed, especially in a thrombocytopenia patient [45]. Significantly, To et al. showed that COVID-19 could be noticed in the saliva sample of diseased persons [46] implying that saliva is an excellent non-invasive sample for coronavirus patient's analysis, observation and contagion control.

When a novel virus discovered, its nucleic acid makes the non-invasive diagnosis of CoV-2 coronavirus genome simple. Furthermore, corona 2019 virus nucleic acid identification has a low sensitivity and high specificity rate, increasing the possibility of undesirable results and perhaps extending the testing timeframe. The emerging COVID-19 treatment and diagnosis plan $\left(5^{\text {th }}\right.$ trial $)$ appropriated assumed infection of pneumonia structures, as well as a clinical feature, measured in Wuhan, China [47]. The emerging new corona-2019 treatment and diagnosis plan $\left(6^{\text {th }}\right.$ trial) removed the difference among other provinces of China with Hubei province [48]. The most suitable reason is that the number of people infects with SARS-CoV-2 outside Hubei province was increased as resident's movement increased. However, Zhang used SHERLOCK technology to establish a test for quick recognition (1hr) of COVID-19. While clinical authentication has not occupied up to date, it needs proof to apply for the rapid diagnosis of corona infection [49]. Recently Peking University research group was demanded to develop a novel tool and technique for rapid formation of the SHERRY library of transcriptome sequencing, which is obliging for fast sequencing of the outbreak of 2019 coronavirus [50].

\section{TREATMENT OF COVID-19}

Here we review the recent data to influence the potential of COVID-19 treatments possibilities. It is vital to attention readers about diagnosis, clinical features, treatment opportunities, and consequences for COVID-19. However, enhanced supportive maintenance relics as a basic treatment, clinical feature as well as clinical efficiency and consequent mediators is still under experimental trials [51]. Maximum upright pre-clinical, as well as clinical statistics on anti-viral treatment, is occupied from other viruses, comprising CoV-2 corona [52]. MERS disease [53] and Ebola [54, 55]. Antiviral therapy has not proven to be effective for the novel coronavirus COVID-19. The treatment of patients occurred through isolation. Now, as defined, the method in which to control the coronavirus disease. The biosafety level (BSL) precaution used by the individual to decrease the spreading ratio of viruses, as well as isolation, diagnosis, and suitable therapy for a patient [56].

Treatment is helpful and symptomatic. The primary stage is to confirm suitable isolation, avoid crowded public areas, never directly contact affected persons, and healthcare staff. Stickily followed the safety rule in the workplace, home and washing hands regularly. Maintaining hydration and nutrition, as well as regulating fever and cough, are typical values. Usual antiviral and antibiotics medicine were used like Oseltamivir must be side-stepped a broad infection of the virus. The person that is affecting by hypoxic will providing a sufficient amount of oxygen, non-invasive venation, high flow nasal cannula, and face mask is designated. Automatic aeration as well as additional corporeal-membrane oxygen support can be essential and needs renal therapy. The antifungals and antibiotics medicine are essential when assumed or confirmed of co-infection. The part of corticosteroid is unconfirmed; although present intercontinental agreement as well as World Health Organization supporter opposite in their usage, according to Chinese rule and regulation ensure acclaim rapid treatment as the reasonable dosage of corticosteroids for corona patients $[57,58]$. Complete strategies for serious care organisation aimed at COVID-19 have been issued by the World Health Organization [59]. Antiviral medications i.e. ritonavir, lopinavir, and ribavir have been used according to SARS/MERS practice. Therefore, ancient control examination of SARS patient's therapy with ritonavir, lopinavir, and ribavirin had enhanced the consequence related to individual ribavirin $[60,61]$. In the study of collective protease enzyme inhibitor, mostly usage against HIV infection did not seem clear result against coronavirus disease while in studied against MERS-CoV virus give positive response [62, 63]. Furthermore, there were no significant changes in mortality within 28-days during the collection of random 199 samples trial of severe coronavirus when given ritonavir/lopinvir 100/400 mg for 14 days twice in the day [64].

IFN- $\alpha$ is administered at a dose of 5 million $U$ (and $2 \mathrm{~mL}$ of sterile water for injection) inhalation in the form of vapour two times each day. Ritonavir/lopinavir $100 \mathrm{mg} / 400 \mathrm{mg}$ used for adults two times in each a day. Ribavirin should be administered by intravenous infusion at a dosage of $500 \mathrm{mg}$ for adults, in conjunction with IFN- $\alpha$ or lopinavir/ritonavir 2 to 3 times per day. Chloro-quine phosphate is given $500 \mathrm{mg}$ orally dose for adults ( $300 \mathrm{mg}$ for chloro-quine), twice daily. 
For adults 3 time/day at a dose of Arbidol $200 \mathrm{mg}$ administered orally used, as well as treatment time is just no more than 10 days [65].

The clinical features and routes of transmission of coronavirus shown in Table

Table 2: Compression of clinical features and transmission routes of $\mathrm{HCoVs}$ virus

\begin{tabular}{|c|c|c|c|c|c|c|}
\hline $\begin{array}{l}\text { Viruses } \\
(\mathrm{HCoVs})\end{array}$ & Classification & $\begin{array}{l}\text { Time of } \\
\text { Incubatio } \\
\mathrm{n}\end{array}$ & $\begin{array}{l}\text { Routs of } \\
\text { transmission }\end{array}$ & Sign and symptoms & Epidemiology & References \\
\hline $\begin{array}{l}\text { Virus } \\
\text { HCoV- } \\
229 \mathrm{E}\end{array}$ & $\alpha-\mathrm{CoV}$ virus & $\begin{array}{ll}2 \text { to } 5 \\
\text { days of } \\
\text { time }\end{array}$ & $\begin{array}{l}\text { Respiratory } \\
\text { droplets } \\
\text { Fomites }\end{array}$ & $\begin{array}{l}\text { Fever Cough, } \\
\text { Malaise, Headache, } \\
\text { Sore throat, } \\
\text { Sneezing, and } \\
\text { Nasal discharge }\end{array}$ & $\begin{array}{l}\text { Globally peak } \\
\text { in winter }\end{array}$ & {$[27-30]$} \\
\hline $\begin{array}{l}\text { Virus } \\
\mathrm{HCoV}- \\
\text { OC43 }\end{array}$ & $\begin{array}{ll}\beta-\mathrm{CoV} & \text { virus } \\
\text { lineage } \mathrm{A} & \end{array}$ & $\begin{array}{ll}2 \text { to } 5 \\
\text { days of } \\
\text { time }\end{array}$ & $\begin{array}{l}\text { Respiratory } \\
\text { droplets } \\
\text { Fomites }\end{array}$ & $\begin{array}{l}\text { Fever, cough, } \\
\text { Malaise, } \\
\text { discharge, } \\
\text { Sore throat, and } \\
\text { Headache }\end{array}$ & $\begin{array}{l}\text { Globally } \\
\text { Peak in } \\
\text { winter }\end{array}$ & [28] \\
\hline $\begin{array}{l}\text { SARS- } \\
\mathrm{CoV}\end{array}$ & $\beta$-CoV lineage $\mathrm{B}$ & 2-11 days & $\begin{array}{l}\text { Respiratory } \\
\text { droplets } \\
\text { Fomites } \\
\text { Fecal-oral }\end{array}$ & $\begin{array}{l}\text { Fever, Myalgia } \\
\text { Headache, Malaise, } \\
\text { Dry cough, Dyspnea } \\
\text { Respiratory distress, } \\
\text { and Diarrhea }\end{array}$ & $\begin{array}{l}\text { 2002-2003 in } \\
\text { China } \\
\text { Globally } \\
\text { thereafter }\end{array}$ & {$[14,15, \& 31]$} \\
\hline $\begin{array}{l}\mathrm{HCoV}- \\
\mathrm{NL63}\end{array}$ & $\alpha-\mathrm{CoV}$ & 2-4 days & $\begin{array}{l}\text { Respiratory } \\
\text { droplets } \\
\text { Fomites } \\
\end{array}$ & $\begin{array}{l}\text { Cough, Rhinorrhea, } \\
\text { Tachypnea, Fever } \\
\text { Hypoxia, and Croup }\end{array}$ & $\begin{array}{l}\text { Globally } \\
\text { Peak in winter }\end{array}$ & [32-35] \\
\hline $\begin{array}{l}\mathrm{HCoV}- \\
\mathrm{HKU} 1\end{array}$ & $\beta$-CoV lineage $\mathrm{A}$ & 2-4 days & $\begin{array}{l}\text { Respiratory } \\
\text { droplets } \\
\text { Fomites }\end{array}$ & $\begin{array}{l}\text { Fever } \\
\text { Running nose } \\
\text { Cough } \\
\text { Dyspnea }\end{array}$ & $\begin{array}{l}\text { Globally } \\
\text { Peak in winter }\end{array}$ & {$[36,37]$} \\
\hline $\begin{array}{l}\text { MERS- } \\
\mathrm{CoV}\end{array}$ & $\beta$-CoV lineage $\mathrm{C}$ & 2-13 days & $\begin{array}{l}\text { Respiratory } \\
\text { droplets } \\
\text { Fomites }\end{array}$ & $\begin{array}{l}\text { Fever, Cough, Chills, } \\
\text { Sore throat, } \\
\text { Myalgia, Arthralgia, } \\
\text { Dyspnea, and } \\
\text { Pneumonia } \\
\text { Diarrhea and vomiting } \\
\text { Acute renal } \\
\text { impairment }\end{array}$ & $\begin{array}{l}2012 \text { in Middle } \\
\text { East } \\
2015 \text { in South } \\
\text { Korea } \\
\text { Endemic in } \\
\text { Middle } \\
\text { East }\end{array}$ & {$[17,18, \& 39]$} \\
\hline $\begin{array}{l}\text { SARS- } \\
\text { CoV-2 }\end{array}$ & $\begin{array}{l}\text { beta-CoV, } \\
\text { lineage B }\end{array}$ & 3-6 days & $\begin{array}{l}\text { Respiratory } \\
\text { droplets } \\
\text { Fomites }\end{array}$ & $\begin{array}{l}\text { Fever } \\
\text { Dry cough } \\
\text { Dyspnea } \\
\text { Myalgia } \\
\text { Headache } \\
\end{array}$ & $\begin{array}{l}\text { 2019-2020 in } \\
\text { China } \\
\text { Globally } \\
\text { thereafter }\end{array}$ & [40] \\
\hline
\end{tabular}

The favipiravir is experimental conduct being tested for the treatment of a new strain of corona COVID-19. China approved such medication for treating novel influenza on February 15, 2020. The major role of the favipiravir drug is to inhibit the RNA dependent RNA polymerase enzyme. Favipiravir is a more operative anti-influenza drug that works by blocking virus replication and acting as anti-influenza viruses such as filo, alpha, flavi, bunya, noro, as well as some RNA viruses. Since inside the cell favipiravir is transformed into an active phosphor-ribosylated and substrate by RNA polymerase of a virus, it inhibits the function of RNA-polymerase. As a result, the scientist believes that the favipiravir drug could have anti-viral activity against SARS-CoV-2 [64, 65].

Additionally, the nucleoside analogue of a remdesivir is a broad anti-viral range that is currently under clinical trial for coronavirus. According to animals' studies, the remdesivir drug can significantly viral load reduced in mice lung tissue affected by the MERS-CoV virus, enhance the function of lungs as well as recovery for injuring lung tissue with the pathological attack. Tocilizumab is a recombinant monoclonal antibody that binds to the interleukin receptor (IL-6) and inhibits its activation as accomplishment other function. Tocilizumab is also used for COVID-19 patients who have achieved high levels of interleukin 6 receptor, the mediator was currently existing in a trial base study [66]. Furthermore, 
there is insufficient evidence for baraticinib, a numb-related kinase inhibitor (NAK), with a primarily great affinity for the kinase (AAK1), a valued regulator of clathrin-mediated endocytosis, anti-IL-1, anakinra used in inhibitor as faviparavir an RNA dependent RNA polymerase and UTI setting in Lombardy, Italy.

Moreover, there is a lack of consistency in the remdesivir as continuously used as an anti-RNA medicine which already approved for Ebola virus therapy same as used for corona 2019 [67]. Previously these treatment medicines needed evidence for esthetical used and suggestion to use against SARS-CoV-2. Arbidol (an anti-viral medicine present in Russia and China), plasma, blood immunoglobulin, interferons, and chloro-quine obtained from COVID-19 affected people are additional medications scheduled for treatment $[68,69, \& 70]$. Furthermore, approvals obtained by traditional Chinese herbs based on the Chinese guiding principle [68]. The list of antiviral therapy for SARS-CoV patients as shown in Table 3 .

Table 3: Antiviral therapy used for COVID-19

\begin{tabular}{c|c|c}
\hline Drug & Administration Methods & Treatment Duration \\
\hline Interferon-Alpha (IFN $\alpha)$ & Inhalation in vapor form & Up to 10 days \\
\hline Lopinavir/ritonavir (Kaletra) & Oral & Up to 10 days \\
\hline Ribavirin & Intravenous infusion 10 days \\
\hline Chloroquine/hydroxychloroquine & Oral & Up to 10 days \\
\hline Arbidol (Umifenovir) & Oral & Up to 10 days \\
\hline Remdesivir & Intravenous infusion 10 days \\
\hline Baraticinib & Oral & Up to 14 days \\
\hline Tocilizumab & Intravenous infection/subcutaneously & Up to 10 days
\end{tabular}

\section{VACCINE DEVELOPMENT}

Vaccines are one of the most effective armamentaria in public health, especially when there is no effective cure for a disease. Since the proclamation of the Covid-19 outbreak [71]. there has been a rush to produce a nontoxic as well as an efficient vaccine in contradiction of SARS-CoV-2. However, the 2020 year will go down a difficult time in the history of combating corona $\mathrm{CoV}-2$, a coronavirus that causes severe respiratory illness. This pandemic brings a strain on health practitioners around the world, resulting in extraordinary health care systems paralysis and a worldwide financial crisis [72]. The task of healthcare professionals, researchers, and politicians in the world were to carry effective prevention and treatment procedures to tackle the pandemic. Beginning of the pandemic, the researcher has been focusing on re-purposing current medicines or creating COVID-19 vaccines [73]. The private and public sectors have collaborated to develop and evaluate applicant vaccines for efficacy as well as protection. One hundred eighty-four vaccines were in preclinical production as of April 22nd, 2021, and 91 were in clinical trials [74]. Regulatory authorities in various parts of the world had given emergency approval to fourteen vaccines by April 2021 [75]. As a result, clinical trial records are available for 14 vaccinations [76-88].

However, several kinds of significant coronavirus protective vaccine developments with different countries as well as they were reporting of this coronavirus, some vaccines are under trial soon will be reportage, including tools that create DNA plasmid vaccine, mRNA-vaccine, viral inactivated protein subunits vaccine, and rAd5-recommbante humanadenovirus or rAd26-simian-adenovirus expression corona CoV-2 S-protein, as well as non-viral expression vector for corona $\mathrm{CoV}-2$ protein. At least 30 vaccine programmes have been announced worldwide so far, with vaccines derived from mRNA, expression using recombinant adenoviral vectors, and inactivated virus having already received regulatory approvals in some countries [89-96]. The major COVID-19 candidate vaccines platforms were listed in Table 4. 
Table 4: Vaccines for COVID-19 in developmental stage

\begin{tabular}{|c|c|c|c|c|c|}
\hline Vaccine Types & Company/Institute & Target & Clinical Trial & Efficacy & Storage \\
\hline mRNA & Pfizer/BioNTech & SARS-CoV-2 & Approved & $95 \%$ & $-70^{0} \mathrm{C}$ \\
\hline mRNA & CureVac & SARS-CoV-2 & Phase 3 & $50-83 \%$ & $2-8^{\circ} \mathrm{C}$ \\
\hline DNA & Innovio & SARS-CoV-2 & Phase 3 & unknown & Room temp \\
\hline Viral Vector & Gamaleya (Ad26-Ad5) & SARS-CoV-2 & Approved & $92 \%$ & $-20^{\circ} \mathrm{C}$ \\
\hline Viral vector & Janssen (Ad26) & SARS-CoV-2 & Approved & $90 \%$ & $-20^{\circ} \mathrm{C}$ \\
\hline Viral vector & $\begin{array}{c}\text { Astrazeneca/Oxford(Chi } \\
\text { mp Adeno) }\end{array}$ & SARS-CoV-2 & Approved & $62 \%$ & $2^{\circ}$ to $8^{\circ} \mathrm{C}$ \\
\hline Viral vector & CanSino (Ad5) & SARS-CoV-2 & Approved & $65 \%$ & $2^{\circ}$ to $8^{\circ} \mathrm{C}$ \\
\hline Protein-VLP & Medicago & SARS-CoV-2 & Phase 3 & unknown & $2^{\circ}$ to $8^{\circ} \mathrm{C}$ \\
\hline Protein VLP & Novavax & SARS-CoV-2 & Phase 3 & $89 \%$ & $2^{\circ}$ to $8^{\circ} \mathrm{C}$ \\
\hline Protein & Clover Biopharma & SARS-CoV-2 & Phase 3 & unknown & $2^{\circ}$ to $8^{\circ} \mathrm{C}$ \\
\hline Protein subunit & $\begin{array}{l}\text { Anhui Zhifei Longcom } \\
\text { (RBD-Dimer) }\end{array}$ & SARS-CoV-2 & Approved & unknown & $2^{\circ}$ to $8^{\circ} \mathrm{C}$ \\
\hline Protein subunit & FBRI Epi VacCorona & SARS-CoV-2 & Approved & unknown & $2^{\circ}$ to $8^{\circ} \mathrm{C}$ \\
\hline Inactivated Virus & $\begin{array}{c}\text { Bharat Biotech } \\
\text { (Covishield) }\end{array}$ & SARS-CoV-2 & Approved & $81 \%$ & $2^{\circ}$ to $8^{\circ} \mathrm{C}$ \\
\hline Viral vector & $\begin{array}{c}\text { Serum Institute of India } \\
\text { (Covishied) }\end{array}$ & SARS-CoV-2 & Approved & $62 \%$ & $2^{\circ}$ to $8^{\circ} \mathrm{C}$ \\
\hline Inactivated Virus & $\begin{array}{l}\text { Sinopharm (Beijing) } \\
\text { BBIBP-CorV }\end{array}$ & SARS-CoV-2 & Approved & $79 \%$ & $2^{\circ}$ to $8^{\circ} \mathrm{C}$ \\
\hline Inactivated & Sinopharm (Wuhan) & SARS-CoV-2 & Approved & $72 \%$ & $2^{\circ}$ to $8^{\circ} \mathrm{C}$ \\
\hline Inactivated Virus & SinoVac & SARS-CoV-2 & Approved & $50-91 \%$ & $2^{\circ}$ to $8^{\circ} \mathrm{C}$ \\
\hline Inactivated & $\begin{array}{l}\text { Chumakov Center } \\
\text { (KoviVac) }\end{array}$ & SARS-CoV-2 & Approved & unknown & $2^{\circ}$ to $8^{\circ} \mathrm{C}$ \\
\hline
\end{tabular}

\section{CONCLUSIONS}

This review article gives an overview of the current state of SARS-CoV-2 that illustrates the up-to-date knowledge in terms of origin, diagnosis, prevalence, treatment, emergency response, public health effects, antiviral drugs, and vaccine development. There is an increasingly growing body of literature on this topic, which should aid in the development of more successful vaccines as well as the best practice for administrating and treating symptomatic cases. Only after the epidemic is over, we will be able to evaluate the economic, social, and health consequences throughout the worldwide catastrophe and draw instructions for upcoming epidemics, particularly regards of global health.

Conflict of interest: None declared.

\section{REFERENCES}

[1] Huang C, Wang Y, Li X, Ren L, Zhao J, Hu Y, et al. 2020. Clinical features of patients infected with 2019 novel coronavirus in Wuhan, China. Lancet. 395:497-506. https://doi.org/10.1016/ S0140-6736(20)30183-5

[2] Liu Y, Gayle A. A, Wilder-Smith A, Rocklov J. 2020. The reproductive number of COVID-19 is higher compared to SARS coronavirus. J. Travel. Med. 27(2):taaa021. https://doi.org/ 10.1093/jtm/taaa021 
[3] Xiao Y. et al. March 17, 2020. Prevention of SARS-CoV-2 infection in patients with decompensated cirrhosis. Lancet. Gastroenterol. Hepatol. 1253 (20): 30080-30087.

[4] Wang P, Anderson N, Pan Y, Poon L, Charlton C, Zelyas N, \& Babcock H. 2020. The SARS-CoV-2 outbreak: diagnosis, infection prevention, and public perception. Clin. chem. 66(5): 644-651.

https://doi.org/10.1093/clinchem/hvaa080.

[5] Update C. Masks And Temperature Checks In Hong Kong. Nevada Public Radio. (2020).

[6] Marsh S. Four cruise ship passengers test positive in UK-as it happened. The Guardian. (2020).

[7] Nikel D. 2020. Denmark closes border to all international tourists for one month. Forbes. Retrieved 13 March 2020.

[8] Jernigan D. B, COVID C, \& Team R. 2020. Update: public health response to the coronavirus disease 2019 outbreakUnited States, February 24, 2020. Morbidity and mortality weekly report. 69(8): 216.

[9] Deerwester J, \& Gilbertson D. 2020. Coronavirus: US says' do not travel'to Wuhan, China, as airlines issue waivers, add safeguards. USA Today. Archived from the original on, 27. (2020).

[10] Chan J. F, To K. K, Tse H, Jin D. Y, Yuen K. Y. 2013. Interspecies transmission and emergence of novel viruses: lessons from bats and birds. Trends. Microbiol. 21:544-55.

[11] Zhu N, Zhang D, Wang W, Li X, Yang, Song J, et al. 2020. A novel coronavirus from patients with pneumonia in China, 2019. N. Engl. J. Med. 2020;382(8):727-33.

[12] Wu A, Peng Y, Huang B, Ding X, Wang X, Niu P, et al. 2020. Genome composition and divergence of the novel coronavirus (2019-nCoV) originating in China. Cell Host Microbe. 27(3):325-8.

[13] Hoffmann M, Kleine-Weber H, Krüger N, Müller M, Drosten C, Pöhlmann S. 2020. The novel coronavirus 2019 (2019-nCoV) uses the SARS-coronavirus receptor ACE2 and the cellular protease TMPRSS2 for entry into target cells. bioRxiv. 2020.01.31.929042.

[14] Wrapp D, Wang N, Corbett KS, Goldsmith JA, Hsieh CL, Abiona O, et al. 2020. Cry-o-EM structure of the 2019 nCoV spike in the prefusion conformation. Science (New York, NY). 367(6483):1260-3.

[15] Zhou P, Yang X L, Wang X. G, Hu B, Zhang L, Zhang W \& Shi Z. L. 2020. A pneumonia outbreak associated with a new coronavirus of probable bat origin. Nature. 579(7798): 270-273.

[16] Hu B, Zeng L. P, Yang X. L, Ge X. Y, Zhang W, Li B, \& Shi Z. L. 2017. Discovery of a rich gene pool of bat SARSrelated coronaviruses provides new insights into the origin of SARS coronavirus. PLoS. Pathog. 13(11): e1006698.

[17] Cunningham C. H, \& Stuart H. O. 1947. Cultivation of the virus of infectious bronchitis of chickens in embryonated chicken eggs. Am. J. Vet. Res. 8(27): 209-212.

[18] Binn L. N, Lazar E. C, Keenan K. P, Huxsoll D. L, Marchwicki R. H \& Strano A. J. 1974. Recovery and characterization of a coronavirus from military dogs with diarrhea. In Proceedings, Annual Meeting of the United States Animal Health Association (1974, December). (No. 78).

[19] Corman V. M, Baldwin H. J, Tateno A. F, Zerbinati R. M, Annan A, Owusu M, \& Drexler J. F. 2015. Evidence for an ancestral association of human coronavirus 229E with bats. J. Virol. 89(23):11858-11870.

[20] Pfefferle S, Oppong,S, Drexler J. F, Gloza-Rausch F, Ipsen A, Seebens A, \& Drosten C. 2009. Distant relatives of severe acute respiratory syndrome coronavirus and close relatives of human coronavirus $229 \mathrm{E}$ in bats, Ghana. Emerg. Infect. Dis. 15(9): 1377.

[21] Pfefferle S, Oppong S, Drexler J. F, Gloza-Rausch F, Ipsen A, Seebens A. et al. 2010. Metagenomic analysis of the viromes of three North American bat species: viral diversity among different bat species that share a common habitat. J. Virol. 84 (24): 13004-13018.

[22] Li X, Song Y, Wong G, \& Cui J. 2020. Bat origin of a new human coronavirus: there and back again. Sci China. Life. Sci. 63(3): 461-462.

[23] Alanagreh L. A, Alzoughool F \& Atoum M. 2020. The human coronavirus disease COVID-19: its origin, characteristics, and insights into potential drugs and its mechanisms. Pathog. 9 (5): 331.

[24] Remais J. 2010. Modelling environmentally-mediated infectious diseases of humans: transmission dynamics of schistosomiasis in China. Modelling parasite transmission and control 2010: 79-98.

[25] Wu J. T, Leung K. \& Leung G. M. 2020. Nowcasting and forecasting the potential domestic and international spread of the 2019-nCoV outbreak originating in Wuhan, China: a modelling study. The Lancet. 395 (10225): 689-697.

[26] Majumder M. \& Mandl K. D. 2020. Early transmissibility assessment of a novel coronavirus in Wuhan. Available at SSRN 2020.

[27] Lipsitch M, Cohen T, Cooper B, Robins J. M, Ma S, James L, \& Murray M. 2003. Transmission dynamics and control of severe acute respiratory syndrome. Sci. 300(5627): 1966-1970.

[28] Majumder M. S, Rivers C, Lofgren E, \& Fisman D. 2014. Estimation of MERS-coronavirus reproductive number and case fatality rate for the spring 2014 Saudi Arabia outbreak: insights from publicly available data. PLo.S Curr. 2014: 6.

[29] Guan W. J, Ni Z. Y, Hu Y, Liang W. H, Ou C. Q, He J. X \& Zhong N. S. 2020. Clinical characteristics of 2019 novel coronavirus infection in China. MedRxiv. (2020). 
[30] Wu Z, \& McGoogan J. M. 2020. Characteristics of and important lessons from the coronavirus disease 2019 (COVID19) outbreak in China: summary of a report of 72314 cases from the Chinese Center for Disease Control and Prevention. Jama. 323(13): 1239-1242.

[31] Chen N, Zhou M, Dong X, Qu J, Gong F, Han Y, \& Zhang L. 2020. Epidemiological and clinical characteristics of 99 cases of 2019 novel coronavirus pneumonia in Wuhan, China: a descriptive study. The lancet. 395 (10223): 507-513.

[32] Bauch C. T \& Oraby T. 2013. Assessing the pandemic potential of MERS-CoV. The Lancet. 382(9893): $662-664$.

[33] Chen H, Guo J, Wang C, Luo F, Yu X, Zhang W \& Zhang Y. 2020. Clinical characteristics and intrauterine vertical transmission potential of COVID-19 infection in nine pregnant women: a retrospective review of medical records. The lancet. 395 (10226): 809-815.

[34] Wang D, Hu B, Hu C, Zhu F, Liu X, Zhang J \& Peng Z. 2020. Clinical characteristics of 138 hospitalized patients with 2019 novel coronavirus-infected pneumonia in Wuhan, China. Jama. 323 (11): 1061-1069.

[35] Li Q, Guan X, Wu P, Wang X, Zhou L, Tong Y \& Feng Z. 2020. Early transmission dynamics in Wuhan, China, of novel coronavirus-infected pneumonia. New. Eng. J. Med. (2020).

[36] Peiris J. S. M, Guan Y \& Yuen K. 2004. Severe acute respiratory syndrome. Nature. Med. 10(12): S88-S97.

[37] Zhu N, Zhang D, Wang W, Li X, Yang B, Song J, \& Tan W. 2020. A novel coronavirus from patients with pneumonia in China, 2019. New. Eng. J. Med. (2020).

[38] Huang C, Wang Y, Li X, Ren L, Zhao J, Hu Y, \& Cao B. 2020. Clinical features of patients infected with 2019 novel coronavirus in Wuhan, China. The lancet. 395 (10223): 497-506.

[39] Ahmed S. S. 2020. The Coronavirus disease 2019 (COVID-19): a review. J. Adv Med. Med. Res. 2020:1-9.

[40]Available:https://www.forbes.com/sites/liset tevoytko/2020/01/30/coronavirus-1st-us-human-to-human-transmissionconfirmed-rightbefore-whoemergencymeeting/\#74479b63fcac(Assessed on $02 \mathrm{Feb} 2020$ ).

[41] Hui DS, Azhar EI, Madani TA, Ntoumi F, Kock R, Dar O \& Petersen E. 2020. The continuing 2019-nCoV epidemic threat of novel coronaviruses to global health-The latest 2019 novel coronavirus outbreak in Wuhan, China. Inter J. Infect. Dis. 91 2020: 264-266.

[42] Parry J. 2020. China coronavirus: cases surge as official admits human to human transmission (2020).

[43] Corman V. M, Landt O, Kaiser M, Molenkamp R, Meijer A, Chu D. K \& Drosten C. 2020. Detection of 2019 novel coronavirus (2019-nCoV) by real-time RT-PCR. Eurosurveillance. 25 (3): 2000045.

[44] Chu D. K, Pan Y, Cheng S. M, Hui K. P, Krishnan P, Liu Y, \& Poon L. L. 2020. Molecular diagnosis of a novel coronavirus (2019-nCoV) causing an outbreak of pneumonia. Clin. Chem. 66 (4): 549-555.

[45] Chan J. F. W, Yuan S, Kok K. H, To K. K. W, Chu H, Yang J, \& Yuen K. Y. 2020. A familial cluster of pneumonia associated with the 2019 novel coronavirus indicating person-to-person transmission: a study of a family cluster. The lancet. 395 (10223): 514-523.

[46] To K. K. W, Tsang O. T. Y, Yip C. C. Y, Chan K. H, Wu T. C, Chan J. M. C \& Yuen K. Y. 2020. Consistent detection of 2019 novel coronavirus in saliva. Clin. Infect. Dise. 71 (15): 841-843.

[47] Wang S. S, Zhou X, Lin X. G, Liu Y. Y, Wu J. L, Sharifu L. M, \& Feng L. 2020. Experience of clinical management for pregnant women and newborns with novel coronavirus pneumonia in Tongji Hospital, China. Curr Med. Sci. 2020:1-5.

[48] Zhao J. Y, Yan J. Y \& Qu J. M. 2020. Interpretations of diagnosis and treatment protocol for novel coronavirus pneumonia (trial version 7). Chinese. Med. J. 133 (11): 1347-1349.

[49] Wang L, Wang Y, Ye D \& Liu Q. 2020. Review of the 2019 novel coronavirus (SARS-CoV-2) based on current evidence. Inter. J. Antimicrob. Agen. 55 (6): 105948.

[50] Di L, Fu Y, Sun Y, Li J, Liu L, Yao J, \& Wang J. 2020. RNA sequencing by direct tagmentation of RNA/DNA hybrids. PNAS. 117(6): 2886-2893.

[51] McCreary E. K Pogue J. M. 2020. on behalf of the Society of Infectious Diseases Pharmacists. COVID-19 Treatment: a review of early and emerging options. In Open. Forum. Infect. Dis. 2020: (Vol. 7)

[52] O'Keefe B. R, Giomarelli B, Barnard D. L, Shenoy S. R, Chan P. K, McMahon J. B, \& McCray P. B. 2010. Broadspectrum in vitro activity and in vivo efficacy of the antiviral protein griffithsin against emerging viruses of the family Coronaviridae. J. Virol. 84 (5): 2511-2521.

[53] Arabi Y. M, Shalhoub S, Mandourah Y, Al-Hameed F, Al-Omari A, Al Qasim E, \& Fowler R. 2020. Ribavirin and interferon therapy for critically ill patients with middle east respiratory syndrome: a multicenter observational study. Clin Infect Dis. 70 (9): 1837-1844.

[54] Siegel D, Hui H. C, Doerffler E, Clarke M. O, Chun K, Zhang L, \& Mackman R. L. 2017. Discovery and synthesis of a phosphoramidate prodrug of a pyrrolo [2, 1-f][triazin-4-amino] adenine C-nucleoside (GS-5734) for the treatment of Ebola and emerging viruses (2017).

[55] WHOQ \& A on coronaviruses (COVID-19). https://www.who. int/newsroom/q-a-detail/q a-coronaviruses

[56] Wang D, Hu B, Hu C, Zhu F, Liu X, Zhang J, \& Peng Z. 2020. Clinical characteristics of 138 hospitalized patients with 2019 novel coronavirus-infected pneumonia in Wuhan, China. Jama. 323 (11): 1061-1069.

[57] Russell C. D, Millar J. E \& Baillie J. K. 2020. Clinical evidence does not support corticosteroid treatment for 2019 nCoV lung injury. The Lancet. 395 (10223): 473-475. 
[58] Zhao J. P, Hu Y, Du R. H, Chen Z. S, Jin Y, Zhou M, \& Cao B. 2020. Expert consensus on the use of corticosteroid in patients with 2019-nCoV pneumonia. Zhonghua jie he he hu xi za zhi=Zhonghua jiehe he huxi zazhi=Chinese. J. Tubercul. Resp. Dis. 43 (3): 183-184.

[59] Huang R, Zhu L, Xue L, Liu L, Yan X, Wang J, \& Wu C. 2020. Clinical findings ofpatients with coronavirus disease 2019 in Jiangsu province, China: A retrospective, multi-center study. PLOS. Negl. Trop. Dis. 14 (5): e0008280.

[60] Chen N, Zhou M, Dong X, Qu J, Gong F, Han Y, \& Zhang L. 2020. Epidemiological and clinical characteristics of 99 cases of 2019 novel coronavirus pneumonia in Wuhan, China: a descriptive study. The lancet. 395(10223): 507-513

[61] Lim J, Jeon S, Shin H. Y, Kim M. J, Seong Y. M, Lee W. J, \& Park S. J. 2020. Case of the Index Patient Who Caused Tertiary Transmission of COVID-19 Infection in Korea: the Application of Lopinavir/Ritonavir for the Treatment of COVID-19 Infected Pneumonia Monitored by Quantitative RT-PCR. J. Korean. Med. Sci. 35 (6) e79-e79.

[62] Lim J, Jeon S, Shin H. Y, Kim M. J, Seong Y. M, Lee W. J, \& Park S. J. 2020. The author's response: case of the index patient who caused tertiary transmission of coronavirus disease 2019 in Korea: the application of Lopinavir/Ritonavir for the treatment of COVID-19 pneumonia monitored by quantitative RT-PCR. J. Korean Med. Sci. 35 (7) e89.

[63] Prajapat M, Sarma P, Shekhar N, Avti P, Sinha S, Kaur H, \& Medhi B. 2020. Drug targets for corona virus: A systematic review. Indian J. Pharma. 52(1): 56.

[64] Cao B, Wang Y, Wen D, Liu W, Wang J, Fan G, \& Wang, C. 2020. A trial of lopinavir-ritonavir in adults hospitalized with severe Covid-19. New Eng. J. Med. (2020).

[65] Dong L, Hu S, \& Gao J. 2020. Discovering drugs to treat coronavirus disease 2019 (COVID-19). Drug Discov. Thera. 14 (1): 58-60.

[66] Biggioggero M, Crotti C, Becciolini A, \& Favalli E. G. 2019. Tocilizumab in the treatment of rheumatoid arthritis: an evidence-based review and patient selection. Drug. Des. Devel. Ther. 13: 57.

[67] Holshue M. L, DeBolt C, Lindquist S, Lofy KH, Wiesman J, Bruce H, \& Pillai S. K. 2020. First case of 2019 novel coronavirus in the United States. New Engl. J. Med.

[68] Jin YH, Cai L, Cheng ZS, Cheng H, Deng T, Fan Y. P, \& Wang X. H. 2020. A rapid advice guideline for the diagnosis and treatment of 2019 novel coronavirus (2019-nCoV) infected pneumonia (standard version). Military. Med. Res. 7 (1): 1-23.

[69] Zhang L, \& Liu Y. 2020. Potential interventions for novel coronavirus in China: A systematic review. J. Med. Virol. 92 (5) $479-490$.

[70] Jie Z, He H, Xi H, \& Zhi Z. 2020. Multicenter collaboration group of Department of Science and Technology of Guangdong Province and Health Commission of Guangdong Province for chloroquine in the treatment of novel coronavirus pneumonia. Expert Consensus on Chloroquine Phosphate for the Treatment of Novel Coronavirus Pneumonia [in Chinese] 10: 1001-0939.

[71] Dutta A. K. 2020. Vaccine Against Covid-19 Disease-Present Status of Development. Indian J. Pediatrics. $2020: 1$ 7.

[72] World Health Organization. Covid-19 vaccines: safety surveillance manual (2020).

[73] Khatiwada A. P, Shrestha N, \& Shrestha S. 2021. Will COVID-19 Lead to a Resurgence of Vaccine-Preventable Diseases?. Infect. Drug Resist. 14, 119.

[74] World Health Organization Draft landscape and tracker of COVID-19 candidate vaccines. World Health Organization: Genova, Switzerland (2021).

[75] Craven J. RAPS: COVID-19 vaccine tracker. https://www.raps. org/news-and-articles/news-articles/2020/3/covid-19vaccinetracker (2021). Accessed 22 May 2021.

[76] Ella R, Reddy S, Jogdand H, Sarangi V, Ganneru B, Prasad S, \& Vadrevu K. M. 2021. Safety and immunogenicity of an inactivated SARS-CoV-2 vaccine, BBV152: interim results from a double-blind, randomised, multicentre, phase 2 trial, and 3-month follow-up of a double-blind, randomised phase 1 trial. The Lancet Infectious Diseases (2021).

[77] Folegatti PM, Ewer KJ, Aley PK, Angus B, Becker S, Belij-Rammerstorfer S, \& Hamlyn J. 2020. Safety and immunogenicity of the ChAdOx1 nCoV-19 vaccine against SARS-CoV-2: a preliminary report of a phase 1/2, single-blind, randomised controlled trial. The Lancet. 396(10249): 467-478.

[78] Jackson L. A, Anderson E. J, Rouphael N. G, Roberts P. C, Makhene M, Coler R. N \& Beigel J. H.2020. An mRNA vaccine against SARS-CoV-2 - preliminary report. New Engl. J. Med. (2020).

[79] Keech C, Albert G, Cho I, Robertson A, Reed P, Neal S \& Glenn GM. Phase 1-2 trial of a SARS-CoV-2 recombinant spike protein nanoparticle vaccine. New Engl J. of Med. 383 (24): 2320-2332.

[80] Logunov D. Y, Dolzhikova I. V, Zubkova O. V, Tukhvatullin A. I, Shcheblyakov D. V, Dzharullaeva A. S, \& Gintsburg A. L. 2020. Safety and immunogenicity of an rAd26 and rAd5 vector-based heterologous prime-boost COVID-19 vaccine in two formulations: two open, non-randomised phase 1/2 studies from Russia. The Lancet. 396(10255): 887-897.

[81] Mulligan M. J, Lyke K. E, Kitchin N, Absalon J, Gurtman A, Lockhart S, \& Jansen K. U. 2020. Phase I/II study of COVID-19 RNA vaccine BNT162b1 in adults. Nature. 586 (7830): 589-593. 
[82] Polack F. P, Thomas S. J, Kitchin N, Absalon J, Gurtman A, Lockhart S, \& Gruber W. C. 2020. Safety and efficacy of the BNT162b2 mRNA Covid-19 vaccine. New Engl. J. Med.383 (27): 2603-2615.

[83] Sadoff J, Le Gars M, Shukarev G, Heerwegh D, Truyers C, de Groot A. M, \& Schuitemaker H. 2020. Safety and immunogenicity of the Ad26. COV2. S COVID-19 vaccine candidate: interim results of a phase 1/2a, doubleblind, randomized, placebo-controlled trial. MedRxiv. (2020).

[84] Voysey M, Clemens S. A. C, Madhi S. A, Weckx LY, Folegatti P. M, Aley P. K, \& Bijker E. 2021. Safety and efficacy of the ChAdOx1 nCoV-19 vaccine (AZD1222) against SARS-CoV-2: an interim analysis of four randomised controlled trials in Brazil, South Africa, and the UK. The Lancet. 397(10269) 99-111.

[85] Xia S, Duan K, Zhang Y, Zhao D, Zhang H, Xie Z, \& Yang X. 2020. Effect of an inactivated vaccine against SARSCoV-2 on safety and immunogenicity outcomes: interim analysis of 2 randomized clinical trials. Jama. 324 (10): 951-960.

[86] Xia S, Zhang Y, Wang Y, Wang H, Yang Y, Gao G. F, \& Yang X. 2021. Safety and immunogenicity of an inactivated SARS-CoV-2 vaccine, BBIBP-CorV: a randomised, double-blind, placebo-controlled, phase 1/2 trial. The Lancet Infectious Dis. 21(1): 39-51.

[87] Zhang Y, Zeng G, Pan H, Li C, Hu Y, Chu K, \& Zhu F. 2021. Safety, tolerability, and immunogenicity of an inactivated SARS-CoV-2 vaccine in healthy adults aged 18-59 years: a randomised, double-blind, placebo-controlled, phase 1/2 clinical trial. The Lancet. Infect. Dis. 21 (2): 181-192.

[88] Zhu F. C, Guan X. H, Li Y. H, Huang J. Y, Jiang T, Hou L. H, \& Chen, W. 2020. Immunogenicity and safety of a recombinant adenovirus type-5-vectored COVID-19 vaccine in healthy adults aged 18 years or older: a randomised, double-blind, placebo-controlled, phase 2 trial. The Lancet. 396 (10249): 479-488.

[89] Zhu F. C et al. 2020. Immunogenicity and safety of a recombinant adenovirus type-5vectored COVID-19 vaccine in healthy adults aged 18 years or older: a randomised, double-blind, placebo-controlled, phase 2 trial. Lancet. 396: 479-488.

[90] Logunov D. Y, Dolzhikova I. V, Zubkova O. V, Tukhvatullin A. I, Shcheblyakov D. V, Dzharullaeva A. S, \& Gintsburg A. L. 2020. Safety and immunogenicity of an rAd26 and rAd5 vector-based heterologous prime-boost COVID-19 vaccine in two formulations: two open, non-randomised phase 1/2 studies from Russia. The Lancet. 396 (10255): 887-897.

[91] Folegatti P. M, Ewer K. J, Aley P. K, Angus B, Becker S, Belij-Rammerstorfer S, \& Hamlyn J. 2020. Safety and immunogenicity of the ChAdOx1 nCoV-19 vaccine against SARS-CoV-2: a preliminary report of a phase 1/2, single-blind, randomised controlled trial. The Lancet. 396 (10249): 467-478.

[92] Xia S, Duan, K, Zhang Y, Zhao D, Zhang H, Xie Z, \& Yang X. 2020. Effect of an inactivated vaccine against SARSCoV-2 on safety and immunogenicity outcomes: interim analysis of 2 randomized clinical trials. Jama. 324 (10), 951-960.

[93] Jackson L. A, Anderson E. J, Rouphael N. G, Roberts P. C, Makhene M, Coler R. N, \& Beigel J. H. 2020. An mRNA vaccine against SARS-CoV-2-preliminary report. New Eng. J. Med.

[94] Anderson E. J, Rouphael N. G, Widge A. T, Jackson L. A, Roberts P. C, Makhene M, \& Beigel J. H. 2020. Safety and immunogenicity of SARS-CoV-2 mRNA-1273 vaccine in older adults. New Engl. J. Med. 383 (25): 2427-2438.

[95] Mulligan M. J, Lyke K. E, Kitchin N, Absalon J, Gurtman A, Lockhart S, \& Jansen K. U. 2020. Phase I/II study of COVID-19 RNA vaccine BNT162b1 in adults. Nature. 586 (7830): 589-593.

[96] Walsh E. E, Frenck R, Falsey A.R, Kitchin N, Absalon J, Gurtman A, \& Gruber W. C. 2020. RNA-based COVID-19 vaccine BNT162b2 selected for a pivotal efficacy study. Medrxiv. 